\title{
FINANCIAL-LAW PROBLEMS IN PROVIDING FREE-OF-CHARGE LEGAL AID IN POLAND. LEGAL COMPARATIVE ASPECTS
}

\author{
Marzena Świstak*
}

\begin{abstract}
Free-of-charge legal assistance remains one of the key areas of state activity. However, the system created is not optimal and its formal, organisational and financial framework needs to be modified. This concerns not only an increase in the amounts of funding, but also the quality of services provided. Not only is the choice of the legal and organisational model of providing legal assistance doubtful, but also the subjective and objective scope of the statutory regulations (including in the context of interpretation of tax regulations) raise some objections. As a postulate for the law as it should stand de lege ferenda), it is proposed to make appropriate legislative changes, aimed not only at clarifying the content of the provisions, or removing the legislative inconsistencies found, but also at thoroughly considering a remodelling of the legal assistance system in Poland. The above conclusions were formulated against the backdrop of the organisational and financial legal solutions adopted in other countries. To this end, the author used the formal-dogmatic and comparative legal methods, and also resorted to the historical method as an auxiliary method, in order to show the evolution of the institution under analysis.
\end{abstract}

Keywords: legal aid, attorney-at-law, advocate, tax on goods and services, personal income tax

Dr. Marzena Świstak, Assistant Professor, Faculty of Law and Administration, Maria Curie-Skłodowska University in Lublin; correspondence address: Pl. Marii CurieSkłodowskiej 5, 20-031 Lublin, Poland; e-mail: marzena.swistak@poczta.umcs.lublin.pl; https://orcid.org/0000-0002-3910-6019. 


\section{INTRODUCTION}

Legal aid is an area of activity of the state, which enjoys a constant broad social demand. In view of the above, it is all the more important to ensure efficient organisational and financial legal mechanisms in this area. It is also important to build an organisational and information framework to ensure that citizens can indeed exercise their constitutional rights effectively. A discussion has been held for many years about the optimal model of legal and civic counselling in Poland, which would meet citizens' needs and, at the same time, ensure the practical effectiveness of the regulations. ${ }^{1}$ As a result of legislative work, an Act was adopted on 5 August 2015, under which, as of 1 January 2016, eligible persons may benefit from an organised system of legal aid. ${ }^{2}$

It should be pointed out as a side note that in comparison with other European (and even non-European) countries, Poland is quite late in structuring the system of legal aid. In many countries, legal solutions in this area were already effective in the 1950 s. $^{3}$ This does not mean, however, that there were no solutions in Poland for providing legal aid to citizens

1 In more detail: Łukasz Bojarski and Grzegorz Wiaderek, "Starania o ustawową regulację dostępu do nieodpłatnej pomocy prawnej - historia i stan obecny," in Obywatel $i$ prawo IV, ed. Agata Winiarska (Warsaw: Instytut Spraw Publicznych, 2009), 13-39 and Łukasz Bojarski, "Dostęp do nieodpłatnej pomocy prawnej - propozycje zmian," in Obywatel i prawo III, ed. Agata Winiarska (Warsaw: Instytut Spraw Publicznych, 2008), 34-67; Jolanta Arcimowicz, Potencjat spoteczny poradnictwa prawnego i obywatelskiego. Analizy i opinie \#132 (Warsaw: Instytut Spraw Publicznych, 2013), 1-5; Grzegorz Chimiak, Poradnictwo prawne i obywatelskie w Polsce. Stan obecny i wizje przysztości (Warsaw: Instytut Spraw Publicznych, 2013), 111-113.

2 Act on Legal Aid, Free-of-charge Civic Counselling and Legal Education of 5 August 2015, Journal of Laws 2019, item 294 as amended, hereinafter referred to as the Legal Aid Act. Due to the entry of the Legal Aid Act into force, a total of 1524 consultancy points were established ( 2 per one powiat [district, county] at a minimum) to provide legal aid for 5 days a week on average for at least 4 hours a day (Article 8(3) of the Legal Aid Act). It is pointed out that a total of 1520 consultancy points are to operate in 2021 (1 point per 25 thousand inhabitants), Szymon Cydzik, "Ministerstwo zwiększa środki na pomoc prawną, accessed November 8, 2020, https://prawo.gazetaprawna.pl/ artykuly/1484690,pomoc-prawna-kwota-bazowa-2021.html.

3 E.g. The legal aid law of 1969 applicable in the South Africa, the Access to Justice Act of 1999 (and the previous act of 1949) applicable in England and Wales, or the legal 
before the Legal Aid Act was enacted. There was a mechanism of ex officio legal assistance provided by advocates and attorneys-at-law at the stage of judicial proceedings (or pre-trial proceedings), once the court found that the applicant met the relevant conditions. ${ }^{4}$ At the out-of-court stage, legal consultancy tasks were carried out by some public administration institutions and bodies, as well as non-governmental organizations which provided free legal assistance as part of their statutory tasks. ${ }^{5}$

Due to the scope of this study, the inclusion of systemic issues regulated in the Polish Legal Aid Act (both in organisational and financial terms) is limited to its first pillar, i.e. provision of legal aid. Selected aspects of this area of state activity (taking into account the comparative perspective) are shown in the context of the tax-law consequences of actions taken by professional legal representatives (attorneys-at-law and advocates). The financing background has also been taken into account, which undoubtedly translates into the shape of the model adopted for the provision of legal aid and the quality of services provided.

\section{LEGAL AID PROVISION SYSTEM - A MODEL APPROACH}

It cannot be ignored that, since the stage of legislative work until the entry of the Legal Aid Act into force, there were constantly critical voices not only about the model of legal aid itself, but also its subjective scope (the group of beneficiaries of legal aid) and objective scope (type and extent of services to be provided). The Polish Ombudsman pointed out that the catalogue of people entitled to receive free legal assistance was incorrectly (too narrowly) outlined in it, which prevented the most deprived persons from using the assistance. Therefore, funds from the state budget

aid law of 1998 in Belgium, or the Legal Aid Act of 1994 (and the previous act of 1956) applicable in the Netherlands.

4 Act of 14 June 1960, Code of Civil Procedure, consolidated text Journal of Laws 2020, item 1740 and Act of 6 June 1997, Code of Criminal Procedure, consolidated text Journal of Laws 2020, item 1740 and Act of 30 August 2002, Law on procedure before administrative courts, consolidated text Journal of Laws 2019, item 2325, as amended.

5 e.g. social assistance institutions, National Labour Inspectorate, district consumer ombudsmen, MP offices. 
allocated to the implementation of this programme are not used with full efficiency. Moreover, it was found that a single-tier structure of legal aid (limited to pre-trial proceedings) was not the optimal solution for an efficient and effective legal aid system. ${ }^{6}$

In this context, it should also be noted that the amendments to the Act to date have not led to a major remodelling of the legal aid system in Poland. Although the circle of beneficiaries and the objective scope of legal aid have been expanded, it has not been decided to build a robust, well-managed and centralized legal aid system that would be based on the activities of a single body (institution) processing applications for legal aid at the pre-trial stage. Such solutions were adopted, for example, in France or the Scandinavian countries. There was also no institution administering the legal aid system, such as the Legal Services Commission operating in England and Wales.

Legal science distinguishes various models of legal aid (with the participation of professionals and various non-governmental organizations), which are fully (or mostly) financed from central or regional budgets. The following models are indicated: charity model, judicare model, welfare model, mixed models and models based on digitalisation. The criterion for distinguishing between the judicare model and the welfare model is the participation of the categories of persons involved in the provision of legal aid. In the welfare model, social and legal support is provided. In the judicare model, the emphasis is shifted to a procedural approach, and the service is provided by professionals (lawyers) who are paid for their services. In the welfare model, on the other hand, social preventive actions are emphasized so as to prevent arising legal problems. ${ }^{7}$ The trends for automation and computerization of legal aid are visible in the model

6 "Wystąpienie Rzecznika Praw Obywatelskich do Prezydenta RP z dnia 6 lipca 2017 r.," accessed November 8, 2020, https:/www.rpo.gov.pl/pl/content/system-nieodplatnej-pomocy-prawnej-wymaga-zmian-rzecznik-pisze-w-tej-sprawie-do-prezydenta-rp.

Michael Zander, "The First Wave," in Access to Justice and the Welfare State, ed. Mauro Cappelletti (Florence: European University Institute, 1981), 27-47; James Gordley, "Variations on a Modern Theme," in Toward Equal Justice: A Comparative Study of Legal Aid in Modern Societies, eds. Mauro Cappelletti, Earl Johnson and James Gordley (Milano: Dott. A. Giuffrè Editore, 1975). 
based on the digitalisation of legal aid. ${ }^{8}$ Therefore, it seems that the model of legal aid used in Polish conditions is based on the dominant participation of professionals (attorneys-at-law and advocates) and supplemented by the activity of non-governmental organizations.

Observing trends throughout Europe, it can be concluded that, of course, none of the models occurs in the socio-economic environment in its pure for. Rather mixed solutions dominate. It seems reasonable, however, to adopt for Polish conditions the option of two-tier legal aid with a single institution administering (coordinating) the provision of legal aid. It should be noted that the lack of centralisation in the system of providing legal aid could result in too much fragmentation. Such a phenomenon has been observed on a large scale, for example, in the decentralised Belgian system based on the operation of numerous autonomous institutions (Committees on Legal Aid) which operate based on rules set exclusively by themselves, which may lead not only to a weakening of the quality of the services provided, but even a breach of the guarantee of civil rights. ${ }^{9}$

Concerning the introduction of a two-tier model of legal aid system structure (as recommended by the Polish Ombudsman), these solutions are not isolated and are applied in such European countries as Germany, Belgium or Croatia. ${ }^{10}$ It is also surprising that, until 2020, it was not decided to take into account the Ombudsman's proposal (reasonable one, as it seems) to allow providing advice through telecommunication means. Scholars in the field criticised the fact that due to the obligation to provide services in person at the legal aid consultation point, the possibility of providing free legal aid by telecommunication means was excluded. ${ }^{11}$ It was only because of the SARS - CoV - 2 (COVID 19) pandemic that appro-

8 Clayton Christensen, The Innovator's Dilemma. When New Technologies Cause Great Firms to Fail (Massachusetts: Harvard Business School Press, 1997).

9 “National Report Belgium, ILAG, Helsinki 2011,” accessed November 10, 2020, http://www.internationallegalaidgroup.org/.

10 "Wystąpienie Rzecznika Praw Obywatelskich do Prezydenta RP z dnia 6 lipca 2017 r.," accessed November 8, 2020, https:/www.rpo.gov.pl/pl/content/system-nieodplatnej-pomocy-prawnej-wymaga-zmian-rzecznik-pisze-w-tej-sprawie-do-prezydenta-rp.

11 Mateusz Kaczocha, Ustawa o nieodptatnej pomocy prawnej oraz edukacji prawnej. Komentarz (Warsaw: LEX el., 2016). 
priate legislative amendments were made to the Act to digitalise the provision of legal aid (although this solution was not carried out correctly from the point of view of legislative technique). ${ }^{12}$

In organisational terms, the Polish system of legal aid is based on the cooperation of local government units and the self-government of legal professions with central government bodies supervising and financing the performance of tasks. Non-governmental organizations carrying out public benefit activities were also included. The agreements concluded between the powiat [district, county] (represented by the Powiat Board) and the municipalities (represented by the mayor) for the purpose of carrying out the task of providing free legal aid, specify in particular the place of provision of legal aid - legal aid consultation points, a schedule listing the days and times on which legal aid will be provided and the rules of cooperation in ensuring access to premises to lawyers providing free legal aid. ${ }^{13}$ Where the powiat carries out the tasks by itself, the starosta (powiat administrator, district head) assigns the premises where the legal aid consultation points will be located and a schedule indicating the days and times during which the legal aid is to be provided. ${ }^{14}$ The starosta is also responsible for disseminating knowledge about

12 The Legal Aid Act was amended by adding Article 28a, with effect from 13 March 2020, which states that during an epidemic threat, during a state of epidemic or state of emergency, the provision of legal aid or the provision of free civic counselling may take place via telecommunication means and outside the premises of the consultation point. Importantly, before obtaining free assistance in the above manner, the beneficiary is also not obliged to submit a written declaration that he is not able to bear the costs of paid legal assistance, and a natural person who is a sole trader does not have to submit a declaration that he/she has not employed other persons in the last year. It can be mentioned as a side note that despite the legislative changes, the provisions of $\$ 3$ and $\$ 4$ of the Ordinance of the Minister of Justice of 21 December 2018 on legal aid and free civic counselling, Journal of Laws 2018, item 2492, as amended remained unchanged, i.e. it prohibits performing activities remotely. This ordinance has not been amended due to the epidemic situation. Of course, recognizing the primacy resulting from the principle of hierarchical sources of law, the statutory regulation prevails. However, taking into account the existing wording of the provisions of the ordinance, introducing appropriate changes in the relevant legal acts would be conducive to transparency and legal certainty.

13 Article 9(1) of the Legal Aid Act.

14 Article 9(3) of the Legal Aid Act. 
the activities of the system of legal aid and free civic counselling among the residents of the powiat. ${ }^{15}$

The entity to organise the implementation of the task is powiat, which to this end concludes annual trilateral agreements (though bilateral may also take place) with the District Bar Council (for advocates) and the District Bar Association of Attorneys-at-Law, competent for the seat of the county authorities on the provision of legal aid in the area of the powiat concerned. ${ }^{16}$ The bodies of the self-government of the professions of advocate and attorney-at-law have the status of entities cooperating with local government units in providing legal aid. ${ }^{17}$ The agreements shall specify the number of advocates and attorneys-at-law who will provide legal aid (while ensuring their even participation in this task) at the designated consultation points, and the schedule of the days and times during which they will operate, the rules for the remuneration of lawyers providing free legal aid and the rules for the use of technical facilities at the consultation point. The District Bar Council and the District Bar Association of Attorneys-at-Law undertake, within the time limit specified in the agreement, to submit to the powiat the lists of advocates and attorneys-a-law and their deputies, who will provide legal aid at each consultation point, together with their contact details. They are selected through internal procedures based on rules of procedure adopted by the Polish Bar Council and The National Bar Council of Attorneys-at-Law concerning the rules for the appointment of advocates and attorneys-at-law to provide legal aid. ${ }^{18}$

The designation of advocates and attorneys-at-law for individual consultation points takes place under a resolution of the District Bar Council and the District Bar Association of Attorneys-at-Law. The Legal Aid Act has also provided for a mechanism for the staffing of legal aid consultation points in the absence of an agreement by 30 November of the year preced-

15 Article 9(4) of the Legal Aid Act.

16 Article 10(1) of the Legal Aid Act.

17 Article 3 (5a) of the Act of 26 May 1982 Law on Advocates, hereinafter referred to as the Law on Advocates; Article 41 (5a) of the Act on Attorneys-at-Law, hereinafter referred to as the Act on Attorneys-at-Law.

18 Article 58 (12)(l) the Law on Advocates and Article 60 (8)(g) of the Act on Attorneys-at-Law. 
ing the year to which the agreement would relate. In such a situation, the starosta shall provide the presidents of bar councils with information on the municipal or powiat premises in which the legal aid consultation points will be located and a schedule indicating the days and times during which it will be provided. On the basis of this information, the president of the District Bar Council and the president of the District Bar Association of Attorneys-at-Law shall indicate advocates and attorneys-at-law to provide legal aid. ${ }^{19}$

The powiat concludes a contract with designated or assigned lawyers on the provision of legal aid by them. The essential terms of the contract are laid down in the Legal Aid Act Law and they also determine the tax status of these lawyers related to the provision of such services. The starosta has an obligation to provide conditions for the provision of legal advice, including to indicate the place and time of their provision, the manner of use of the premises made available and the facilities contained therein, and the rules on access to the database of legal acts enabling the provision of legal aid, as reflected in the content of the contracts concluded. ${ }^{20}$

The evaluation of the performance of legal aid tasks on the basis of collective information provided by starostas for a given year shall be carried out by the Minister of Justice by 30 June of the following year, and the results are communicated to the Joint Commission of the Central Government and Local Government, which is a forum for developing a common position of the central government and local government. ${ }^{21}$ As indicated in the scholarly opinion, the review assumes, in particular, the assessment of the degree of task implementation, effectiveness, reliability and quality of task implementation, the correct use of public funds assigned for the implementation of the task, as well as verification of documentation kept for the task being carried out.

19 Article 10(2) of the Legal Aid Act.

20 Article 6 of the Legal Aid Act.

21 Article 16 (1) and (2) of the Legal Aid Act; Article 2 (1) of the Act of 6 May 2005 on the Joint Commission of the Central Government and Local Government and representatives of the Republic of Poland in the European Committee of the Regions, Journal of Laws 2005, No. 90, item 759, as amended. 


\section{LEGAL AID - THE TAX-LAW ASPECTS}

Pursuant to the general rule contained in the Legal Aid Act, legal advice in consultation points is provided in person by advocates and attorneys-at-law, and in particularly justified cases, trainee advocates or trainee attorneys-at-law by their authorization. In the light of the provisions of the Act, legal aid covers quite a wide spectrum of activities. ${ }^{22}$ Scholars in the field point out that the substantive scope of legal aid falls within the notion of "providing legal aid" by an attorney-at-law and advocate. ${ }^{23}$ The statutory definition of legal aid as a task of central government administration performed, as a rule, by powiats, is included in the constitutional legal basis ${ }^{24}$ and is a solution to provide natural persons at the pre-trial stage with legal advice or indication of the possibility of an amicable settlement of a dispute, without the need to take legal action.

As a general rule, an attorney-at-law or advocate is obliged to "provide legal aid in person" (taking into account the possibility of using telecommunication tools during an epidemic). The Legal Aid Act provides that only in particularly justified cases will there be a basis for granting authorization to a trainee lawyer. The ratio legis of such a solution is the elimination of the reprehensible practice, which would consist in the fact that an attorney-at-law or advocate who has a contract with the powiat would be permanently substituted by a trainee attorney-at-law or a trainee advocate, who would have the appropriate authorization. This way of proceeding would circumvent the rules. However, the rules for granting the trainee lawyer an authorization in a situation when there are particularly justified circumstances have not been specified. The relevant regulations were not

22 Article 3(1) of the Legal Aid Act.

23 See Article 6(1) the Act on Attorneys-at-Law and Article 4(1) of the Act on Advocates. The same view in: Cezary Chabel, Zakres przedmiotowy pojęcia "nieodptatna pomoc prawna" oraz wytaczenia ustawowe (Warsaw: LEX el., 2015). These conclusions with respect to the substantive scope of providing legal aid are confirmed by the content of model contracts posted on the website of the Ministry of Justice, especially $\$ 5$ and $\$ 7$ of the model contracts, accessed July 13, 2020, https://darmowapomocprawna.ms.gov.pl/pl/aktualnosci/news,7874,wzory-umow-na-swiadczenie-nieodplatnej pomocy.html.

24 Article 166 (2) of the Constitution of the Republic of Poland, Journal of Laws 1997, No. 78, item 483, as amended. 
referred to in this regard. In view of the above, it is appropriate to refer to the provisions of the acts relating to professional organizations of attorneys-at-law or advocates. ${ }^{25}$ It is important to distinguish between a substitution power of attorney by an attorney-at-law or advocate, and an authorization for a trainee attorney-at-law or trainee advocate to substitute an attorney-at-law or advocate to a certain extent.

It should be mentioned that legal aid may also be provided by lawyers (who meet the requirements of the Act on Free Legal Assistance) from non-governmental organisations carrying out public benefit activities, including them, on an open tender basis, in the staffing of half the legal aid consultation points in the powiat. ${ }^{26}$ Only in the case of failure to staff a legal aid point, which was entrusted by the powiat of a non-governmental organisation (as a result of a failure to select, conclude a contract with a non-governmental organisation by a starosta, or termination of the contract), the task of providing legal aid in this consultation point is transferred to advocates and attorneys-at-law. ${ }^{27}$ The mixed system referred to above is not an exceptional solution adopted only in Poland. One could point, for example, to the solutions found in Belgium, where the legal aid system is composed of Legal Aid Committees, each consisting of: members of local bar associations, appointed by the presidents of local bar associations (half of the total number of the Committee), members of social welfare organisations (25\% of the total number) and members of other organisations providing legal aid, such as consumer organisations (the remaining 25\%). ${ }^{28}$ There are also European solutions with a broader catalogue of entities entitled to provide legal aid than in Poland (e.g. Croatia, where trade unions and law clinics operating at universi-

25 For more on the topic, see: Marzena Świstak, "Pełnomocnictwo substytucyjne a upoważnienie aplikanta do zastępowania radcy prawnego i adwokata - wybrane zagadnienia. Stan obecny i postulaty de lege ferenda," in Samorząd a prawo do sadu, ed. Jacek Sobczak (Lublin: Stowarzyszenie Naukowe Pro Scientia Iuridica, 2016), 125-144.

26 Articles 5 and 11 of the Legal Aid Act.

27 Article 11 and 12 of the Legal Aid Act.

28 “National Report Belgium, ILAG, Helsinki 2011,” accessed November 7, 2020, http://www.internationallegalaidgroup.org/. 
ty law faculties were also allowed to participate in providing legal aid). ${ }^{29}$ In the practice of providing legal aid by attorneys-at-law (or advocates), a number of issues have arisen at the point of contact between the application of the analysed Act of a lex specialis nature and the tax law provisions. Undoubtedly, one of such issues is the definition of the VAT taxation rules. ${ }^{30}$ A question has therefore been posed: Should the provision of legal aid under the principles laid down in the Legal Aid Act be regarded a VAT taxable activity? This issue has become the subject of consideration by the tax authorities.

According to the provisions of the VAT Act, the following activities are VAT taxable: the supply of goods and services for consideration in the territory of the country. ${ }^{31}$ The provision of services referred to above shall be understood as any provision to a natural person, legal entity or organisational unit without legal personality which does not constitute a supply of goods within the meaning of Article 7 of the VAT Act. ${ }^{32}$ The definition of provision of services within the meaning of the VAT Act is very broad. The provision shall be understood as any behaviour (both action and omission) which is not a supply within the meaning of Article 7 of the Act. A service will be only such a performance in the case of which there is a direct recipient who earns a benefit of a property nature. Therefore, an activity is subject to taxation only if it is performed as part of a legal relationship of an obligating nature, and one of the parties to the transaction may be considered a direct beneficiary of the activity. ${ }^{33}$ For a given transaction to be taxable by value added tax, it should be carried out by a taxpayer. ${ }^{34}$ The

29 "Free Legal Aid Act, Ministerstwo Sprawiedliwości," accessed November 7, 2020, http://www.mprh.hr/beneficiaries-of-the-free-legal-aid.

30 Act of 11 March 2004 on the Tax on Goods and Services, Journal of Laws of 2020, item 106, as amended, hereinafter referred to as the VAT Act.

31 Article 5 (1) point 1 of the VAT Act.

32 Article 8 (1) of the VAT Act.

33 There should be a direct and clear link between the payment received and the performance for the benefit of payer.

34 The VAT Act provides that, as defined by the regulations, taxable persons are legal persons, organisational units without legal personality and natural persons who run the business activity referred to in Article 15(2) of the VAT Act independently of the purpose or result of such activity (Article 15(1) of the VAT Act). 
condition for a given activity to be VAT taxable is that two conditions are met: firstly, the activity should be included in the catalogue of activities subject to VAT, and secondly, it must be carried out by an entity which, in connection with its performance as part of the business activity, will be a taxpayer of the tax on goods and services. Business activity includes all activities of producers, traders or service providers, including those of natural resources and farmers, as well as activities of the liberal professions. ${ }^{35}$ In particular, activities involving the use of goods or intangible assets on a continuous basis for profit-making purposes fall within the scope of this concept. ${ }^{36}$

The independently performed business activity referred to in Art. 15 (1) of the VAT Act, however, the activities for which the revenues are listed in Art. 13 points (2) to (9) of the PIT Act, if, due to the performance of these activities, these persons are related to the person who orders the performance of these activities by legal bonds establishing the legal relationship between the ordering party and performing the activities ordered as to the conditions for performing these activities, remuneration and liability of the ordering party towards third parties. ${ }^{37}$ The use of the word "independently" in the wording of Article 15 (3) point 3 of the VAT Act, excludes taxation of employees and other persons, as long as they are related to the employer by an employment contract or other legal relationship creating bonds (subordination relationship) between the employer and the employee as to working conditions, remuneration and the employer's responsibility. This means that the revenues from the activities performed should not only be listed in Article 13 points (2) to (9) of the Personal Income Tax Act, but also other objective criteria must be met, including whether the activity of the service provider is based on economic risk, and thus who assumes responsibility for the services provided.

35 In the case of a business activity, it is not merely the formal conditions for such an activity, but the fulfilment of the substantive features (see: Paweł Terpiłowski, "VAT przy usługach świadczonych na podstawie umowy zlecenia," accessed January 12, 2020, https:// ksiegowosc.infor.pl/podatki/vat/zalres-opodatkowania/2866915,VAT-przy-uslugach-swiadczonych-na-podstawie-umowy-zlecenia.html.

36 Article 15 (2) of the VAT Act.

37 Article 15 (3) point 3 of the VAT Act. 
Only and exclusively the activities, in which there are ties between the ordering party and the person performing the ordered activities, which establish a legal relationship in terms of conditions for performing these activities, remuneration and liability of the ordering party towards third parties, do not constitute an independent economic activity within the meaning of Art. 15 (2) of the act on tax on goods and services, Therefore, a person who, under a signed contract, establishes with the ordering party an economic relationship analogous to the employment relationship without bearing the economic risk related to the activities performed, will not be a taxpayer within the meaning of the VAT Act. Meeting the requirements that exclude the independence of action by concluding a legal relationship between the ordering party and the contractor as to the conditions for performing the outsourced activities, remuneration and liability of the ordering party to third parties, allows the performed activities to be excluded from VAT taxation.

The key to the assessment of the tax-law character is primarily the method of defining the "liability of the ordering party towards third parties". This is a factor that differentiates, in the light of the provisions of the VAT Act, running a business (a prerequisite for the status of a VAT taxpayer) from any other type of professional activity that does not give rise to being taxable under the VAT Act. Only when the person accepting the order is liable to third parties for the activities performed as part of the order. The liability for the performance of activities so understood indicates who bears the risk of the activity, and thus indicates the exclusion from the sphere of independence (and from the group of VAT taxpayers) of the entity which is not responsible towards third parties for the result of the work performed. Therefore, it is important for the parties to the obligation relationship to define correctly, in accordance with their intention, the type of activity, the conditions for the provision of these activities, remuneration and liability to third parties. Then it will be possible to correctly determine the tax-law status of a given entity. If the analysis of the civil-law contract (legal relationship) between the parties to the contract shows that all these three conditions are met, the contractor cannot be considered a VAT taxpayer. At the same time, the failure to fulfil any of the conditions means that the contractor acts as a VAT taxpayer. Therefore, the following conclusions follow from the provisions 
of the VAT Act. ${ }^{38}$ In order to recognize that certain activities performed by a natural person do not constitute an independently pursued business activity and thus remain outside the provisions of the Value Added Tax Act, it is important to meet all the elements listed in Art. 15 (3) point 3 of the VAT Act.

By applying the foregoing considerations to the provision of legal aid, it must be held that, as regards the first condition, i.e. the determination of the conditions for the performance of an activity, the use of the infrastructure and the internal organisation of the ordering party is in principle included in the substance of a typical service contract to provide legal aid by a natural person. The use of the infrastructure and the internal organisation of the ordering party means that the person receiving the order also does not bear economic risks in this regard (which is closely linked to the way in which remuneration is determined, that is the second condition which affects the determination of the tax-law status). In practice, the verification of the fulfilment of the second condition boils down to determining whether the contract provides for a fixed remuneration. Where the contract provides for a fixed remuneration, there can be no question about the economic risk being incurred by an attorney-at-law or advocate. The third condition, namely liability to third parties, is met if, according to the contract, the liability is on the part of the ordering party and not on the part of the actual contractor who accepts the order, which excludes the independent nature of his activities. The condition will also be met if the contract does not provide for (does not introduce) such liability.

Where all the conditions set out in Article 15(3) point 3 of the Act are met, activities performed by an attorney-at-law (or advocate) under a contract concluded with the powiat shall not be taxable by the tax on goods and services. Accordingly, the remuneration paid in this respect is not subject to value added tax and the attorney-at-law is not obliged to issue an invoice and pay the tax on goods and services. ${ }^{39}$

38 Article 15 (3) point 3 of the VAT Act.

39 As in: Individual interpretation issued by the Director of the National Tax Information of 15 April 2019, no. 0113-KDIPT1-1.4012.86.2019.2.AK, accessed January 12, 2020, http://sip.mf.gov.pl and Letter of 23 April 2019, no.0115-KDIT1- 
On the other hand, referring to the provisions of the PIT Act, it should be noted that the catalogue of revenues to be included as the revenue from activities carried out in person is set out in Article 13 of the PIT Act. ${ }^{40}$ Revenue from activities carried out in person as set out in Article 10(1) point 2 of the Act shall be deemed to be revenue from the provision of services, under an agreement of contract work or a specific-task contract, obtained exclusively from a natural person carrying out a business activity, a legal person and its organisational unit and an organisational unit without legal personality, with the exception of revenue from contracts concluded in the course of a non-agricultural economic activity carried out by a taxable person and revenues referred to in point 9)..$^{41}$

Therefore, the classification of revenue as the revenue from personally performed activities referred to in Article 13(8)(a) of the PIT Act depends on the cumulative fulfilment of the following conditions: 1) the commissioned service will be performed personally by the taxpayer, i.e. without the participation of persons employed under an employment contract, contract work or a specific-task contract, who would perform activities related to the essence of that service, 2) the civil-law contract has been concluded with a natural person performing business activity or a legal person and its organisational unit or an organisational unit not having legal personality ${ }^{42}$,

1.4012.446.2019.3.MM, accessed January 12, 2020, http://sip.mf.gov.pl, Letter of 6 November 2017., no. 0112-KDIL1-2.4012.350.2017.2.MR, accessed January 12, 2020, http://sip.mf.gov.pl, Individual interpretation issued by the Director of the National Treasury Information of 18 September 2014, IPPP2/443-690/14-4/MT/MM, accessed January 12, 2020, http://sip.mf.gov.pl. Similarly: Letter of 25 October 2018, of the Director of the National Treasury Information, no. 0115-KDIT1-1.4012.637.2018.1.MN, accessed January 12, 2020, http://sip.mf.gov.pl.

40 Article 13 (8) of the PIT Act.

41 Article 13(9) of the PIT Act provides for revenue earned under enterprise management contracts, managerial contracts or contracts of a similar nature, including revenue from such contracts concluded as part of the taxpayer's non-agricultural business activity except for the revenue referred to in point 7), i.e. revenue earned by persons, irrespective of the method of appointment of these persons, who are members of management boards, supervisory boards, committees or other governing bodies of legal persons.

42 If civil law contracts (in particular contract work, specific-task contracts) were concluded with natural persons who do not carry out business activity, revenues from the provision of services to those entities could not be included in the source of revenue referred to in 
3) the civil law contract will not be concluded within the scope of business activity conducted by the taxpayer. If an attorney-at-law (advocate) provides free legal assistance in person under a contract with the powiat, apart from his business activity, his revenue may be included in the category of revenue from the activity performed in person.

\section{RULES OF FINANCING LEGAL AID}

As already mentioned, the area of activity of the state involving the provision of legal aid to certain groups of citizens is a task that has been delegated to powiats (acting independently or in agreement with the municipalities in the area of a given powiat). ${ }^{43}$ Such a delegation of central government administration tasks has its legal basis in the Act on powiat government. ${ }^{44}$ Imposing, by way of a statutory act, the obligation to perform by a powiat the tasks specified in another legal act is acceptable in the Polish order and finds a constitutional basis. ${ }^{45}$ In such a case, a statutory act should specify the mode of delegation and the manner of performing the delegated tasks and point out that changes in the scope of tasks and competences of local government units take place along with appropriate changes in the distribution of public income.

An order for a local authority to carry out a task must be linked to the provision of adequate financial resources for the performance of the task. This task is financed from the state budget from the part at

Article 13(8)(a) of the PIT Act. As a consequence, revenue from the provision of services under contract work agreements and specific-task contracts concluded with natural persons not conducting business activity should be included in revenue from the so-called other sources (Individual interpretation issued by the Director of the National Treasury Information of 12 March 2015, no. IBPBI/1/415-1409/14/SK, accessed January 12, 2020, http://sip. mf.gov.pl).

${ }^{4}$ The same view in: Provincial Administrative Court in Wrocław, Judgment of 25 May 2018, Ref. No. IV SAB/Wr 27/18, LEX no. 2510555.

44 Article 8 (1) of the Legal Aid Act in conjunction with Article 4 (4) of the Act of 5 June 1998 on Powiat Government, consolidated text Journal of Laws of 2020, item 920.

45 Article 166 (2) of the Constitution of the Republic of Poland, Journal of Laws 1997, No. 78, item 483, as amended. 
the disposal of the voivodeship governors (wojewoda, a body of the central government at the regional level) by granting a specific-purpose subsidy to powiats. The institution of specific-purpose subsidy is regulated in principle by the provisions of the Act on public finance. ${ }^{46}$ Specific-purpose subsidies are funds designed, inter alia, for financing or co-financing of central government tasks and other tasks assigned to local government units by law. ${ }^{47}$ It should be stressed that a specific-purpose subsidy is a unilateral, free-of-charge and, in principle, non-refundable benefit. ${ }^{48}$ It is intended for making a specific expenditure for a given purpose and in due time. In accordance with the provisions of the Act on public finance, the amounts of specific-purpose subsidies for central government tasks and other tasks assigned by separate laws to local government units shall be determined by the administrators of the budgetary part according to the rules adopted in the State budget to determine expenditure of a similar kind, unless otherwise provided for by separate provisions. ${ }^{49}$ Specific-purpose subsidies for the implementation of tasks in the field of central government administration and other tasks assigned by laws shall be delegated to the local government unit by the voivodeship governor in sufficient advance for the full and timely performance of the tasks. ${ }^{50}$

The regulation of the Legal Aid Act in this area constitutes a lex specialis to the provisions of the Act on public finance and therefore takes precedence in application. On the other hand, the provisions of the Act on public finance apply to the subsidy in question to an extent not regulated by the Legal Aid Act. Therefore, the provisions of the Act on

46 Act of 27 August 2009 on Public Finance, consolidated text Journal of Laws 2019, item 869, as amended, hereinafter referred to as the Act on public finance.

47 Article 127 (1) (a) of the Act on public finance.

48 Agnieszka Mikos-Sitek, "Prawo budżetowe," in Agnieszka Mikos-Sitek and Piotr Zapadka, Prawo finansów publicznych (Warsaw: Wydawnictwo C.H. Beck, 2018), 108; Mateusz Kaczocha, Ustawa o nieodptatnej pomocy prawnej oraz edukacji prawnej. Komentarz (Warsaw: LEX el., 2016).

49 Article 129 of the Act on Public Finance.

50 Article 149 (1) of the Act on Public Finance. 
public finance should be applied e.g. for the assessment of the impact of the failure to use the specific-purpose subsidy in a given financial year. ${ }^{51}$

The provisions of the Legal Aid Act stipulate that the provision of legal aid is financed from the state budget from the part at the disposal of voivodeship governors by the granting of specific-purpose subsidies to powiats. The amount of the subsidy is currently determined annually by the Minister of Justice in agreement with the Minister competent for budgetary matters in accordance with the procedure and time limits laid down in the provisions of the Act on public finance concerning the work on the draft budget law. ${ }^{52}$

The specific-purpose subsidy granted is allocated in $91 \%$ for salaries for contracts concluded with attorneys-at-law and advocates, while if the running of a consultation point is entrusted to a non-governmental organisation - for the selected non-governmental organisation, $6 \%$ - to cover the costs of organizational and technical support, and in 3\% to legal education tasks entrusted to the non-governmental organisation. ${ }^{53}$ The voivodeship governor, as the authority commissioning the task, may carry out checks and evaluations of the performance of the task by the powiat, in particular the efficiency, reliability and quality of its implementation, as well as the correct spending of public funds. For contracts concluded with non-governmental organisations, its implementation is to be checked by the starosta in accordance with the rules laid down in the Act of 24 April 2003 on public benefit activity and volunteerism. ${ }^{54}$ This is why there is

51 Article 168(1) of the Act on public finance provides that subsidies granted from the state budget in their part not used by the end of the financial year or within the period specified in a regulation issued under Article 181(3) must be returned to the state budget respectively by 31 January of the following year or within 21 days from the date specified in that regulation. Specific-purpose subsidies granted to local government units for the performance of tasks in the field of central government administration and other tasks delegated under statutory acts, in the part not used by the end of a given year, are subject to return to the state budget in the part in which the task was not performed, within the time limit specified in paragraph 1 (Article 168 (6) of the Act on public finance).

52 Article 19 of the Legal Aid Act and Article 138 (6) of the Act on public finance.

53 Article 20 (1) of the Legal Aid Act; Robert Rynkun-Werner, Magdalena Wasylkowska-Michór and Beata Paxford, Ustawa o nieodptatnej pomocy prawnej oraz edukacji prawnej. Komentarz (Warsaw: Wydawnictwo C. H. Beck, 2016).

54 Article 11(8) of the Legal Aid Act. 
a dual-model system for financing legal aid. The first model is based on settlements with natural persons (attorneys-at-law and advocates) consisting in the payment of remuneration under contracts concluded with those entities, against VAT invoices or bills. The second, based on the model of specific-purpose subsidy for entities outside the public finance sector, transferred on the basis of contracts concluded. The method of settlement and verification of the performance of the task assigned was determined in each case in resolutions adopted by legislative bodies of the local government units. In the case of non-governmental organisations, the correct performance of the task was assessed on the basis of the reports submitted by those organisations. ${ }^{55}$

The basis for determining the amount of the subsidy to be granted for the task (legal aid) is the base amount (12 times the product of the base amount and the multiplier). The multiplier is to be calculated in such a way that the number of inhabitants of the district as of 31 December of the year preceding the financial year by two years, as determined by the President of the Central Statistical Office, is divided by 25 000, provided that it may not be less than 2 and greater than 35. The multiplier expressed as a non-integer shall be rounded up to an integer if the first decimal digit is equal to or greater than 5 , or rounded down if the first decimal digit is less than 5. The Minister of Justice, in consultation with the minister competent for budgetary matters, shall determine annually, by regulation, the sum of the base amount, taking into account the expenditure limits $^{56}$ and the need to ensure the proper organisation of the system of legal aid, free civic counselling and legal education. ${ }^{57}$

The total maximum limit of expenditure resulting from the entry into force of the Act for the years 2016-2025 has been set at PLN 1,047,700 thousand. The base amounts and limits of expenditure from the state budget are presented respectively in Table 1 and Table 2 .

55 "Raport NIK, Funkcjonowanie systemu nieodpłatnej pomocy prawnej," LOP.430.001.2018, accessed November 10,2020, https:/www.nik.gov.pl/kontrole/P/17/090/.

56 Article 28 of the Legal Aid Act.

57 Article 20 of the Legal Aid Act. 


\section{Table 1.}

\begin{tabular}{|c|c|c|c|c|c|}
\hline \multicolumn{7}{|c|}{$\begin{array}{c}\text { Regulations of the Minister of Justice in the period 2016-2021. } \\
\text { Sum of the base amount (in PLN). }\end{array}$} \\
\hline 2016 & 2017 & 2018 & 2019 & 2020 & $2021^{*}$ \\
\hline 5150 & 5217 & 5217 & 5500 & 5500 & 5500 \\
\hline
\end{tabular}

${ }^{*}$ Ordinance of the Minister of Justice of $26^{\text {th }}$ August 2020 on the base amount in 2021, Journal of Laws 2020, item 1501- effective from January 1, 2021.

Source: Own study (analysis of the provisions of the Ordinance of the Minister of Justice on the base amount for 2016-2021, LEX el.)

Table 2.

Maximum limit of the State budged expenditure (on legal aid) for the period 2016 - 2021. Amount (in PLN thousands)

\begin{tabular}{|c|c|c|c|c|c|}
\hline 2016 & 2017 & 2018 & 2019 & 2020 & 2021 \\
\hline $94,183,200$ & $96,161,047$ & $98,565,074$ & $100,930,635$ & $103,352,971$ & $105,833,441$ \\
\hline
\end{tabular}

Source: Own study (Article 28 of the Legal Aid Act)

In the budgets of local government units, the funds allocated for the implementation of the task were entered respectively in section 755 justice, chapter 75515 - legal aid. The amount of the specific-purpose subsidy in the years 2016 to 2020 is presented in Table 3.

Table 3.

\begin{tabular}{|c|c|c|c|c|}
\hline \multicolumn{5}{|c|}{$\begin{array}{c}\text { Budgetary acts for the years } 2016 \text { to } 2020 \text { expenses (in PLN thousand) } \\
\text { related to the performance of the task of legal aid }\end{array}$} \\
\hline 2016 & 2017 & 2018 & 2019 & 2020 \\
\hline 94,037 & 95,478 & 95,416 & 100,914 & 100,518 \\
\hline
\end{tabular}

Source: Own study (analysis of budgetary acts for 2016-2020, LEX el.)

A general conclusion can be drawn from the content of the data presented, that the amount of the specific-purpose subsidy allocated for the implementation of statutory tasks remained within the statutory lim- 
its and did not show any major fluctuations, or showed even a minimal upward trend (except for a slight decrease in the amount of funding in 2018 and 2020). For base amounts, their increase could be observed in 2017 and 2019, however, despite government announcements, the base amount remained unchanged in the following years (2019-2021). In view of the growing expected inflation and fluctuations in this regard, the above solution should be assessed with criticism. ${ }^{58}$

\section{CONCLUSIONS}

The foregoing analysis, including the results of the audit of the system of providing legal aid in Poland, allow us to formulate a thesis that free legal and civic counselling, as well as legal education, are still the areas of state activity that enjoy high social demand. The organisational and information framework of the legal aid system, however, still needs to be improved. This includes both the quality of the services provided and an increase in their availability through wide-ranging information campaigns. ${ }^{59}$ Unfortunately, it should be mentioned that the shortcomings and possible weaknesses of the system are not new elements. They were reported already at the stage of adopting the Act and they have still not been removed, despite the fact of the Act being effective for several years. It seems that in such an important area for society, more firm and effective steps should be taken leading to greater effectiveness of the regulations

58 Szymon Cydzik, "Ministerstwo zwiększa środki na pomoc prawną," accessed November 8, 2020, https://prawo.gazetaprawna.pl/artykuly/1484690,pomoc-prawna-kwota-bazowa-2021.html; "Rada Polityki Pieniężnej, Projekcje inflacji i PKB (lipiec 2020)," accessed November 8, 2020, https:/www.nbp.pl/home.aspx?f=/polityka_pieniezna/dokumenty/projekcja_inflacji_2020_lipiec.html.

59 Similarly: “Ocena Ministra Sprawiedliwości z realizacji zadań z zakresu nieodpłatnej pomocy prawnej, nieodpłatnego poradnictwa obywatelskiego oraz edukacji prawnej za 2019 r.," accessed August 20, 2020, https://darmowapomocprawna.ms.gov.pl/pl/aktualnosci/news, 14919, ocena-ministra-sprawiedliwosci-z-realizacji-zadan.html and "Informacja o wynikach kontroli, Funkcjonowanie systemu nieodpłatnej pomocy prawnej," LOP 403.001.2018, accessed August 20, 2020, https://www.nik.gov.pl/aktualnosci/pomoc-prawna-nieodplatna-potrzebuje-pomocy.html. 
adopted. At the same time, it should be noted that the numerous requests for interpretation submitted to the Director of the National Tax Information and the ongoing disputes between taxpayers and tax authorities show that the interpretation of tax provisions in the context of providing legal aid still generates ambiguities, despite the passage of time. In the absence of clear and unambiguous regulations, it is necessary to fully regulate all the issues related to the provision of services by an attorney-at-law in the contract concluded with the powiat. This is not an optimal solution. It seems that the aim should be to precisely define in the Act the manner and conditions of providing services, by ensuring uniformity of positions presented by the tax authorities as to the exclusion of the activity of a taxpayer (attorney-at-law or advocate) from VAT taxation, and to determine the method of qualification of their income. The lack of appropriate regulations in this respect may result in an unfavourable interpretation for the taxpayer, and, consequently, generate the risk of tax arrears.

Despite these difficulties in interpretation and the signals of the relatively low efficiency of the legal aid system, it is not possible, at the same time, to ignore the fact that the Act fills a years-long legal void in such an important area of state activity and in view of such pressing social needs. It is undoubtedly a good step towards taking account of social needs and increasing legal awareness. It should not, however, be frozen in its original legislative framework, but, on the contrary, a thorough analysis of the solutions adopted from the point of view of the criterion of their effectiveness should be carried out with a deep insight. In this area, consideration should be given to a deeper reformulation of the system, by introducing a twotier system, similar to that of solutions used in other European countries. Apart from the defining of full public funding, it would also be desirable to introduce the inflationary adjustment of the base amount, which is the basis for determining the amount of the specific-purpose subsidy. There is no doubt that social demand for this type of service is growing (the number of cases is increasing), and therefore it would not be good to lead to a situation which occurred, for example, in Belgium, where, despite the increase in cases at certain consultation points, the amount of subsidy has remained at the same level for a long time, generating a reduction in the remuneration of professionals, and consequently contributing to a reduction in the quality of services provided. Perhaps a solution would 
also be to consider the introduction of a model of partial participation of the recipients of legal aid in the costs of providing thereof (with the degree of this participation being adjusted to the material situation of the applicant). This is intended to enable rational use of financial resources, as well as to increase the responsibility of the individual for initiating and conducting proceedings. Such solution was implemented in e.g. Croatia, the Netherlands and Germany.

\section{REFERENCES}

Arcimowicz, Jolanta. Potencjat spoteczny poradnictwa prawnego i obywatelskiego. Analizy i opinie \#132. Warsaw: Instytut Spraw Publicznych, 2013.

Bojarski, Łukasz. "Dostęp do nieodpłatnej pomocy prawnej - propozycje zmian." In Obywatel i prawo III, edited by Agata Winiarska, 34-67. Warsaw: Instytut Spraw Publicznych, 2008.

Bojarski, Łukasz, and Grzegorz Wiaderek. "Starania o ustawową regulację dostępu do nieodpłatnej pomocy prawnej - historia i stan obecny." In Obywatel i prawo IV, edited by Agata Winiarska, 13-39. Warsaw: Instytut Spraw Publicznych, 2009.

Chabel, Cezary. Zakres przedmiotowy pojęcia "nieodptatna pomoc prawna” oraz wytaczenia ustawowe. Warsaw: LEX el., 2015.

Chimiak, Grzegorz. Poradnictwo prawne i obywatelskie w Polsce. Stan obecny i wizje przysztości. Warsaw: Instytut Spraw Publicznych, 2013.

Christensen, Clayton. The Innovator's Dilemma. When New Technologies Cause Great Firms to Fail. Massachusetts: Harvard Business School Press, 1997.

Cydzik, Szymon. "Ministerstwo zwiększa środki na pomoc prawną." Accessed November 8, 2020. https://prawo.gazetaprawna.pl/artykuly/1484690,pomoc-prawna-kwota-bazowa-2021.html.

Gordley, James. "Variations on a Modern Theme." In Toward Equal Justice: A Comparative Study of Legal Aid in Modern Societies, edited by Mauro Cappelletti, Earl Johnson, and James Gordley. Milano: Dott. A. Giuffrè Editore, 1975.

Kaczocha, Mateusz. Ustawa o nieodptatnej pomocy prawnej oraz edukacji prawnej. Komentarz. Warsaw: LEX el., 2016.

Mikos-Sitek, Agnieszka. "Prawo budżetowe." In Mikos-Sitek, Agnieszka, and Piotr Zapadka, Prawo finansów publicznych, 85-143. Warsaw: C. H. Beck, 2018.

Rynkun-Werner, Robert, Magdalena Wasylkowska-Michór, and Beata Paxford. Ustawa o nieodptatnej pomocy prawnej oraz edukacji prawnej. Komentarz. Warsaw: C. H. Beck, 2016. 
Świstak, Marzena. "Pełnomocnictwo substytucyjne a upoważnienie aplikanta do zastępowania radcy prawnego i adwokata - wybrane zagadnienia. Stan obecny i postulaty de lege ferenda." In Samorzad a prawo do sqdu, edited by Jacek Sobczak, 125-144. Lublin: Stowarzyszenie Naukowe Pro Scientia Iuridica, 2016.

Terpiłowski, Paweł. "VAT przy usługach świadczonych na podstawie umowy zlecenia.” Accessed January 12, 2020. https://ksiegowosc.infor.pl/podatki/vat/ zalres-opodatkowania/2866915,VAT-przy-uslugach-swiadczonych-na-podstawie-umowy-zlecenia.html.

Zander, Michael. "The First Wave." In Access to Justice and the Welfare State, edited by Mauro Cappelletti. Florence: European University Institute, 1981. 